\title{
Influence of diet on growth yields of rumen micro-organisms in vitro and in vivo: influence on growth yield of variable carbon fluxes to fermentation products
}

\author{
M. Blümmel ${ }^{1 *}$, A. Karsli ${ }^{2}$ and J. R. Russell ${ }^{2}$ \\ ${ }^{1}$ Institute for Animal Production in the Tropics and Subtropics (480), University of Hohenheim, 70599 Stuttgart, \\ Germany \\ ${ }^{2}$ Department of Animal Science, lowa State University, Ames, IA 50011, USA
}

(Received 29 November 2001 - Revised 18 March 2003 - Accepted 10 May 2003)

\begin{abstract}
The efficiency of rumen microbial production (EMP) in vitro and in vivo was examined for three roughages (lucerne (Medicago sativa L.) hay, oat (Avenia sativa L.)-berseem clover (Trifolium alexandrinum cultivar BigBee) hay and maize (Zea mays L.) crop residue (MCR)) and for five isonitrogenous $(106 \mathrm{~g}$ crude protein $(\mathrm{N} \times 6 \cdot 25) / \mathrm{kg})$ diets formulated from lucerne hay, oat-berseem clover hay, MCR, soyabean meal and maize grain to provide degradable intake protein for the production of $130 \mathrm{~g}$ microbial protein $/ \mathrm{kg}$ total digestible nutrients. EMP in vivo was determined by intestinal purine recovery in sheep and ranged from 240 to $360 \mathrm{~g}$ microbial biomass $/ \mathrm{kg}$ organic matter truly degraded in MCR and in one of the diets respectively $(P<0.05)$. EMP in vitro was estimated by the substrate degraded:gas volume produced thereby (termed partitioning factor, $\mathrm{PF}(\mathrm{mg} / \mathrm{ml})$ ) at times of estimated peak microbial production and after 16.0 and $24.0 \mathrm{~h}$ of incubation. For the diets, PF values were significantly related to EMP in vivo at peak microbial production $(P=0 \cdot 04)$, but not after $16.0(P=0.08)$ and $24.0 \mathrm{~h}(P=0.66)$. For roughages, PF values were significantly related to EMP in vivo only when measured after $16.0 \mathrm{~h}(P=0.04)$. For MCR and diets, a close non-linear relationship was found between PF values at peak microbial production and EMP in vivo $\left(R^{2} 0 \cdot 99, P<0 \cdot 0001\right)$ suggesting a maximum EMP in vivo of 0.39. Low gas production per unit substrate degraded (high PF) was associated with high EMP in vivo. The in vitro study of the products of fermentation, short-chain fatty acids, gases and microbial biomass (by purine analysis) after $16 \cdot 0 \mathrm{~h}$ of incubation showed very strong relationships $\left(R^{2} \geq 0 \cdot 89, P<0 \cdot 0001\right)$ between short-chain fatty acids, gases and gravimetrically measured apparent degradability. Except for maize grain, the true degradability of organic matter estimated by neutral-detergent solution treatment agreed with the sum of the products of fermentation $\left(R^{2} 0 \cdot 81\right.$, $P=0.0004)$. After $16.0 \mathrm{~h}$ of incubation, the synergistic effects of diet ingredient on diets were greater for microbial biomass $(18 \%)$ than for short-chain fatty acids and gas production (7\%). It is concluded that measurement of gas production only gives incomplete information about fodder quality; complementation of gas measurements by true degradability measurements is recommended.
\end{abstract}

Fermentation products: In vitro gas production: Microbial efficiency

Proportionally high conversion of rumen-degraded feed into microbial biomass, i.e. a high efficiency of microbial production (EMP), is desired in ruminant animal nutrition because it leads to efficient feed $\mathrm{N}$ and $\mathrm{C}$ utilization (Beever, 1993; Leng, 1993; Van Soest, 1994). It was, for example, demonstrated that the nature and fermentation characteristics of feed protein $(\mathrm{N})$ and carbohydrates can affect EMP (Brown \& Pittman, 1991; Clark et al. 1992; Sinclair et al. 1995), thus rejecting the assumption of a constant EMP still prevalent in some feeding systems (Ausschuss für Bedarfsnormen der Gesellschaft für Ernährungsphysiologie der Haustiere, 1986; Agriculture and Food Research Committee, 1993). As an exception, the Cornell net carbohydrate and protein system (Fox et al. 1992; Russell et al. 1992; Sniffen et al. 1992) considers feed- or diet-specific differences in EMP, suggesting their prediction by the analysis of numerous feed carbohydrate and $\mathrm{N}$ fractions with associated degradation rates (National Research Council, 1996).

A simpler in vitro technique for the estimation of EMP of roughages was suggested by Blümmel et al. (1997) and consists of a combination of two in vitro measurements in one $24.0 \mathrm{~h}$ incubation using rumen inoculum. Gas volume produced during the incubation is recorded as described by Menke et al. (1979) and the substrate truly degraded is gravimetrically quantified by the modification of the technique of Tilley \& Terry (1963) suggested by Goering \& Van Soest (1970). The degradability measurement

Abbreviations: EMP, efficiency of microbial production; LH, lucerne hay; MCR, maize crop residue; MG, maize grain; OBH, oat-berseem clover hay; OM, organic matter; PF, partitioning factor; SBM, soyabean meal; SCFA, short-chain fatty acid; $t_{1 / 2}$, time of half asymptotic gas production.

* Corresponding author: Dr M. Blümmel, present address, ILRI-South Asia Project, c/o ICRISAT, Patancheru 502324, Andhra Pradesh, India, fax +91 40 241238, email m.blummel@cgiar.org 
reflects how much substrate was used for the formation of all products of fermentation, namely short-chain fatty acids (SCFA), gases and microbial biomass. The gas measurement indicates how much substrate was used for the formation of SCFA and gases, since SCFA and gas production are very closely associated stoichiometrically (Wolin, 1960; Beuvink \& Spoelstra, 1992; Blümmel \& Ørskov, 1993; Blümmel et al. 1999a). The substrate truly degraded $(\mathrm{mg})$ : gas thereby produced $(\mathrm{ml})$ was termed the partitioning factor (PF) and, proportional to the amount of substrate degraded, low gas production (high $\mathrm{PF}$ ) was indicative of a high EMP in vitro (Blümmel et al. 1997). For roughages, PF values from 2.75 to $4.45 \mathrm{mg} / \mathrm{ml}$ approximately reflected $\mathrm{Y}_{\mathrm{ATP}}$ ranges from 10 to 32 (for review, see Blümmel et al. 1997).

Microbial growth, however, has several stages, notably lag, growth, stationary and decline phases (Van Soest, 1994). Microbial growth phases relative to incubation time will vary between substrates and comparisons of EMP in batch systems at different microbial growth phases might result in false conclusions. This might be the case with PF analysis fixedly conducted after $24.0 \mathrm{~h}$ incubations without regard for substrate-specific differences in microbial growth kinetics.

In the present study, eight roughages and mixed diets were investigated with two objectives in mind. The first was to examine if PF comparisons at similar microbial growth phases would result in greater agreement between in vitro and in vivo estimates of EMP. Second, by studying the products of microbial degradation, the study addresses some fundamental considerations about in vitro techniques, namely the comparative advantages and disadvantages of measuring substrate disappearance (Goering \& Van Soest, 1970) or appearance of fermentation products such as gases (Menke et al. 1979; Steingass \& Menke, 1986).

\section{Materials and methods}

\section{Feeds and feeding}

The forages used for in vivo experimentation have previously been described in detail by Karsli (1998). In brief, a first harvest oat (Avenia sativa L.)-berseem clover (Trifolium alexandrinum cultivar BigBee) was mowed at late vegetative stage and third harvest lucerne (Medicago sativa L.) was mowed at first flowering stage. Maize (Zea mays L.) crop residues (MCR) were obtained from maize fields and all three roughages were round-baled and ground through a $50 \mathrm{~mm}$ screen of a tub-grinder shortly before the start of the feeding trial. The three roughages were offered in restricted amounts and ad libitum (about $115 \%$ of intake; only results on ad libitum intake are reported in the present paper) to six rumen- and duodenum-cannulated wether sheep in a $6 \times 6$ Latin square design. Five diets designed from the three roughages were adjusted to approximately isonitrogenous levels by maize grain (MG) and soyabean meal (SBM) incorporation and were offered in a consecutive experiment to five sheep in a $5 \times 5$ Latin square design. The diets had degradable intake protein levels to provide $130 \mathrm{~g}$ microbial protein $/ \mathrm{kg}$ total digestible nutrients, consumed according to level 1 of the Nutrient Requirements of Beef Cattle computer program (National Research Council, 1996). In the calculation of dietary crude protein, degradable protein intake and total tract digestible organic matter (OM; see later) of MCR, oat-berseem hay $(\mathrm{OBH})$ and lucerne hay $(\mathrm{LH})$ determined in a previous experiment (Karsli, 1998) were used. Each period lasted for $22 \mathrm{~d}$, consisting of a $12 \mathrm{~d}$ adaptation and a $10 \mathrm{~d}$ collection period. The animals were housed in individual pens under controlled $\left(25^{\circ} \mathrm{C}\right)$ temperature conditions and had free access to water and a trace minerals salt block.

\section{Digesta flow, digestibility measurements and estimates of in vivo microbial biomass production}

Cr-mordanted fibre $(1.5 \mathrm{~g})$ containing approximately $20 \mathrm{~g}$ $\mathrm{Cr} / \mathrm{kg}$ was added to the rumen daily at 08.00 and 20.00 hours to determine digesta flow as described by RojasBourillon et al. (1987). Feed and ort samples were collected on days 12 to 16 of each period and composited. On days 14, 15 and 16 of each period, $200 \mathrm{ml}$ duodenal digesta and $15 \mathrm{~g}$ fresh faecal matter were collected four times perd. Sampling time was advanced $2.0 \mathrm{~h}$ perd so that the samples collected over the $3 \mathrm{~d}$ represented each $2 \cdot 0 \mathrm{~h}$ of a $24.0 \mathrm{~h}$ cycle. After collection, samples were frozen and stored. Approximately $1500 \mathrm{ml}$ rumen contents were collected from the ventral sac of the rumen for the isolation of rumen microbes by differential centrifugation according to Adamu et al. (1989).

DM concentrations of feeds, orts and faeces were determined by drying in a forced-air oven at $60^{\circ} \mathrm{C}$ for $48.0 \mathrm{~h}$. Duodenal digesta samples and the bacterial pellets were freeze-dried. Dried feed, duodenal digesta and faecal samples were ground through a $1 \mathrm{~mm}$ screen. Dry duodenal digesta and faecal samples were composited on an equal dry weight basis for each animal in each period. OM concentrations of dried feeds, orts, duodenal digesta and faecal samples were determined as the weight loss during combustion at $600^{\circ} \mathrm{C}$ for $2.0 \mathrm{~h}$ in a muffle furnace. Concentrations of neutral-detergent fibre and acid-detergent fibre in dry feeds, orts, duodenal digesta and faecal samples were determined by the sequential procedure of Van Soest \& Robertson (1985) and N concentrations were analysed by the Kjeldahl method. Purine concentrations of duodenal digesta and rumen microbial pellet samples were determined by the procedure of Zinn \& Owens (1986). The amounts of $\mathrm{N}$ and truly degraded $\mathrm{OM}$ in the rumen were calculated by correcting the amounts of apparently degraded $\mathrm{N}$ and $\mathrm{OM}$ for microbial $\mathrm{N}$ and $\mathrm{OM}$ as determined by the $\mathrm{N}$ :purines and $\mathrm{N}: \mathrm{OM}$ ratios in the rumen bacterial pellet. Similarly, microbial biomass produced was calculated by dividing duodenal purine flow by the concentration of purines in the DM of the bacterial pellet.

\section{In vitro incubation procedures}

Substrates were incubated in $100 \mathrm{ml}$ calibrated glass syringes commonly used for the Hohenheim gas-production test (Menke et al. 1979; Steingass \& Menke, 1986), but the incubation protocol followed was that of Blümmel \& Becker (1997). Briefly, four replicates of $500 \mathrm{mg}$ air-dry substrate were weighed into the syringes and these were 
incubated with $40 \mathrm{ml}$ mixed suspension of rumen digesta. This suspension consisted of $10 \mathrm{ml}$ rumen contents, $10 \mathrm{ml}$ bicarbonate buffer, $5 \mathrm{ml}$ macro- and micro-minerals solutions $(0.002 \mathrm{ml}$ of which was micro-mineral solution) and $15 \mathrm{ml}$ distilled water. As a modification to the method of Blümmel \& Becker (1997), no $\mathrm{NH}_{4} \mathrm{HCO}_{3}$ was used in the preparation of the bicarbonate buffer, which consisted entirely of $\mathrm{NaHCO}_{3}(0.467 \mathrm{M})$. Rumen inoculum was collected from a ruminally fistulated German Hinterwalder cow kept on a medium- to good-quality grass hay diet before morning feeding. The rumen inoculum consisted of about $600 \mathrm{ml}$ rumen contents and $400 \mathrm{ml}$ rumen particulate matter/l. For details of inoculum handling and preparation, see Blümmel \& Becker (1997).

\section{In vitro gas volume and apparent DM and true organic} matter degradability measurements

Five different incubations were conducted. The rate and extent of in vitro gas production from roughages, concentrates and diets were obtained during a $96 \cdot 0 \mathrm{~h}$ incubation with gas volume recordings after $2,4,6,8,10,12,24,30$, $36,48,54,60,72$ and $96.0 \mathrm{~h}$ of incubation. The rate and extent of gas production were calculated using an exponential model $\mathrm{y}=\mathrm{V}\left(1-\mathrm{e}^{-\mathrm{ct}}\right)$, in which $\mathrm{y}$ is the gas volume at time $t, \mathrm{~V}$ is the asymptotic value of gas production and $\mathrm{c}$ is the the fractional rate of gas production.

In vitro true $\mathrm{OM}$ degradability was determined after recording the gas volume and terminating the incubation at the desired time by transferring the entire syringe contents through the outlet of the syringe into $600 \mathrm{ml}$ spoutless Berzelius beakers. The syringes were rinsed twice with neutral-detergent solution (prepared without sodium sulfite and amylase) by dispensing $25 \mathrm{ml}$ neutral-detergent solution through the outlet into the syringe each time. The syringe was shaken each time to remove residual particles, after which the contents were added to the respective Berzelius beaker. The procedure of Goering \& Van Soest (1970) for the determination of true digestibility was then applied by refluxing the incubation residue for $1.0 \mathrm{~h}$ and recovering the undigested matter on filter crucibles (porosity 2). The PF value at a given time of incubation was calculated as OM truly degraded ( $\mathrm{mg}$ ):gas volume produced thereby $(\mathrm{ml})$. The PF values were determined after 24.0 and $16.0 \mathrm{~h}$ of incubation as well as at the time at which half-maximum gas production was achieved $\left(t_{1 / 2}\right)$. Preliminary data about kinetics of in vitro gas production and microbial biomass yield had suggested that $t_{1 / 2}$ could serve as a common time denominator to facilitate acrosssubstrate comparisons of $\mathrm{PF}$ values (Blümmel et al. $1999 b), t_{1 / 2}$ in the model $\mathrm{y}=\mathrm{V}\left(1-\mathrm{e}^{-\mathrm{ct}}\right)$ was calculated as:

$$
t_{1 / 2}=\ln 2 / \mathrm{c} \text {. }
$$

In vitro apparent $\mathrm{DM}$ degradability was determined after $16.0 \mathrm{~h}$ of incubation by high-speed centrifugation. The entire syringe content was transferred into centrifuge tubes and centrifuged at $20000 \mathrm{~g}$ for $30 \mathrm{~min}$ at $4^{\circ} \mathrm{C}$. The supernatant fraction was carefully removed with a Pasteur pipette and stored for SCFA and $\mathrm{NH}_{3}$ analysis. The syringes were washed three times with $\mathrm{NaCl}$ solution $(4 \mathrm{~g} / \mathrm{l})$, each time dispensing $15 \mathrm{ml}$ of solution through the spike into the syringe. The syringe was shaken each time to remove residual particles and the contents were added to the respective centrifuge tube. After completing rinsing of the syringes, centrifugation was repeated once and the supernatant fraction was discarded. The pellets were lyophilized overnight and residual moisture was removed by drying in a forced-air oven at $105^{\circ} \mathrm{C}$ for $3.0 \mathrm{~h}$. In vitro apparent $\mathrm{DM}$ degradability equals DM substrate incubated $(\mathrm{mg})-(\mathrm{DM}$ pellet (mg) - DM blank pellet (mg)), where blank pellet weight was determined by centrifugation of $4 \times 40 \mathrm{ml}$ rumen suspension sampled at the $0 \mathrm{~h}$ of incubation.

In vitro short-chain fatty acid production, ammonia concentration, stoichiometrical calculations and purine analysis after 16.0 h of incubation

SCFA in the supernatant fraction were analysed by GC (Hewlett Packard 5880 A (Hewlett Packard, Palo Alto, CA, USA) with flame ionization detection) as described by Aiple (1993). Gas production was calculated from SCFA according to Blümmel et al. (1999a) and measured gas volumes were corrected for pressure as described in the same paper. The amounts of $\mathrm{C}, \mathrm{H}$ and $\mathrm{O}$ required for the production of SCFA (including the isoacids) and associated fermentative $\mathrm{CO}_{2}, \mathrm{CH}_{4}$ and $\mathrm{H}_{2} \mathrm{O}$ were summed according to Blümmel et al. (1997). ATP production from the acids was calculated using standard values from the literature as described by Blümmel et al. (1997). $\mathrm{NH}_{3}-\mathrm{N}$ in the supernatant fraction was determined by the Kjeldahl method using direct steam distillation. Purines (adenine and guanine) were analysed by HPLC as described by Makkar \& Becker (1999). Purines were analysed after ball-milling the pellets obtained by high-speed centrifugation in the determination of in vitro apparent DM degradability and net purine production $(\mu \mathrm{mol})$ was calculated based on pellet weights and purine analysis. The purine concentration in the microbial biomass was estimated by purine analysis of the lyophilized blank microbial pellet.

\section{Statistical analysis}

Statistical differences in the variables were analysed using ANOVA procedure (1988; Statistical Analysis Systems, Cary, NC, USA) and mean values were separated by applying least squares difference procedures with the probability level set to $P=0 \cdot 05$. Significance statements refer to this probability level unless otherwise stated. The computer program GraphPad Prism (1994; GraphPad Inc., San Diego, CA, USA) was used to calculate the rate and extent of gas production by non-linear regression and also to calculate the simple linear regression relationships used in the present study.

\section{Results}

Roughages, concentrates, diets and in vivo experimentation

The chemical compositions of LH, OBH, MCR, SBM, MG and diets (diets 1 to 5) are summarized in Table 1. 
Table 1. DM, organic matter, crude protein $(\mathrm{N} \times 6.25)$, neutral-detergent fibre and acid-detergent fibre in soyabean meal, maize (Zea mays L.) grain, lucerne (Medicago sativa L.) hay, oat (Avenia sativa L.)-berseem clover and (Trifolium alexandrinum cultivar BigBee) hay and maize crop residue and of diets made from these components*

\begin{tabular}{|c|c|c|c|c|c|c|c|c|c|c|}
\hline & SBM & $M G$ & LH & ОВН & MCR & Diet $1 \dagger$ & Diet $2 \ddagger$ & Diet 3§ & Diet $4 \|$ & Diet 5 \\
\hline $\mathrm{DM}(\mathrm{g} / \mathrm{kg})$ & 944 & 914 & 930 & 931 & 933 & 934 & 933 & 930 & 932 & 928 \\
\hline OM (g/kg DM) & 932 & 987 & 918 & 892 & 936 & 938 & 935 & 928 & 939 & 940 \\
\hline $\mathrm{CP}(\mathrm{g} / \mathrm{kg} \mathrm{DM})$ & 436 & 79 & 181 & 139 & 41 & 107 & 106 & 109 & 103 & 104 \\
\hline $\operatorname{NDF}(g / k g ~ D M)$ & 206 & 169 & 420 & 622 & 757 & 659 & 645 & 610 & 628 & 554 \\
\hline ADF ( $\mathrm{g} / \mathrm{kg} \mathrm{DM})$ & 136 & 30 & 284 & 374 & 433 & 369 & 359 & 339 & 356 & 315 \\
\hline
\end{tabular}

SBM, soyabean meal; MG, maize grain; LH, lucerne hay; OBH, oat-berseem clover hay; MCR, maize crop residue; OM, organic matter; CP, crude protein; NDF, neutral-detergent fibre; ADF, acid-detergent fibre. * Composition of diets.

†Diet 1: $0.790(\mathrm{MCR})+0.05(\mathrm{MG})+0.16 \mathrm{SBM}$

‡Diet 2: $0.690 \mathrm{MCR}+0.103 \mathrm{OBH}+0.083 \mathrm{MG}+0.124 \mathrm{SBM}$

Diet 3: $0.450 \mathrm{MCR}+0.35 \mathrm{OBH}+0.15 \mathrm{MG}+0.05 \mathrm{SBM}$

|Diet 4: $0.691 \mathrm{MCR}+0.103 \mathrm{LH}+0.103 \mathrm{MG}+0.103 \mathrm{SBM}$

9 Diet 5: $0.450 \mathrm{MCR}+0.350 \mathrm{LH}+0.20 \mathrm{MG}$

The mean crude protein $(\mathrm{N} \times 6.25)$ content of diets was 106 (range $103-109) \mathrm{g} / \mathrm{kg}$ with little variation between the diets. For roughages, the crude protein content was lowest in MCR and highest in LH, while the reverse was true for fibre constituents. All diets included two roughages and at least one concentrate. MCR and MG were included in all diets.

Daily intakes of roughages and diets, OM truly degraded in the rumen and EMP are summarized in Table 2. DM and $\mathrm{OM}$, crude protein and fibre intakes were substantially higher in $\mathrm{LH}$ and $\mathrm{OBH}$ than in MCR and diets. For roughages, OM truly degraded in the rumen was substantially higher for $\mathrm{LH}$ than $\mathrm{OBH}$ and MCR, but only small differences in $\mathrm{OM}$ truly degraded in the rumen were observed for the diets. The EMP in vivo, expressed as $\mathrm{g}$ microbial biomass production $/ \mathrm{kg} \mathrm{OM}$ truly degraded in the rumen, was lowest for MCR and highest for diet 5 . The diets had higher EMP than roughages, but the difference was small for $\mathrm{LH}$ and $\mathrm{OBH}$.

In vitro gas volume, substrate degradability measurements and partitioning factor values: their relationships with the efficiency of microbial production in vivo

Asymptote, $\mathrm{c}$ and $t_{1 / 2}$ of in vitro gas production, in vitro true OM degradability and PF of concentrates, roughages and diets are summarized in Table 3 . There were significant differences in $\mathrm{V}, \mathrm{c}$ and $t_{1 / 2}$ between components and between diets. It can be calculated that the mean $\mathrm{V}$ value of the diets was slightly $(1.5 \%)$, but significantly, higher $(P<0.05)$ than expected from the summation of the respective values of the feed components according to their proportion in the diets. The rate of gas production of the diets was about $13 \%$ higher than calculated from the incubations of the dietary components and their respective proportions in the diets. Similarly, $t_{1 / 2}$ was about $13 \%$ less in the diets than calculated from the dietary components.

Gas volumes, in vitro true $\mathrm{OM}$ degradability and $\mathrm{PF}$ measured at $t_{1 / 2}$ and after $16.0 \mathrm{~h}$ of incubation differed significantly between components and diets. $t_{1 / 2}$ varied widely from 7.6 and $8.5 \mathrm{~h}$ for SBM and LH to 21.5 and $22.7 \mathrm{~h}$ for MG and MCR respectively. The difference between the shortest and longest $t_{1 / 2}$ in diets was about $2 \cdot 0 \mathrm{~h}$. All $t_{1 / 2}$ were $<24 \mathrm{~h}$ and gas volumes and in vitro true OM degradability after $24.0 \mathrm{~h}$ were consequently higher than their respective $t_{1 / 2}$ and $16 \cdot 0 \mathrm{~h}$ values (Table 3 ), but the reverse was true for PF values after $24.0 \mathrm{~h}$ (results not shown). Gas volumes measured at $t_{1 / 2}$ were not exactly $50 \%$ of the asymptotic volumes, reflecting some deviation in the repeatability of gas production kinetics in different incubations.

$\mathrm{PF}$ at $t_{1 / 2}$ was significantly related to EMP in vivo in the diets, but not in the roughages (Fig. 1). In vivo EMP across diets and roughages were not significantly related to gas volumes but were related to the in vitro true OM

Table 2. Daily intakes ( $\mathrm{g} / \mathrm{kg}$ live weight) of $\mathrm{DM}$, organic matter and crude protein $(\mathrm{N} \times 6 \cdot 25)$, organic matter truly degraded in the rumen and efficiency of microbial production*

(Mean values for six sheep)

\begin{tabular}{lcccccccc}
\hline & LH & OBH & MCR & Diet 1 & Diet 2 & Diet 3 & Diet 4 & Diet 5 \\
\hline DM intake & $45 \cdot 1^{\mathrm{a}}$ & $31 \cdot 1^{\mathrm{b}}$ & $16 \cdot 9^{\mathrm{c}}$ & $17 \cdot 1^{\mathrm{c}}$ & $17 \cdot 7^{\mathrm{c}}$ & $22 \cdot 0^{\mathrm{c}}$ & $18 \cdot 8^{\mathrm{c}}$ & $21 \cdot 7^{\mathrm{c}}$ \\
OM intake & $41 \cdot 4^{\mathrm{a}}$ & $28 \cdot 6^{\mathrm{b}}$ & $15 \cdot 9^{\mathrm{c}}$ & $16 \cdot 0^{\mathrm{c}}$ & $16 \cdot 5^{\mathrm{c}}$ & $20 \cdot 5^{\mathrm{c}}$ & $18 \cdot 3^{\mathrm{c}}$ & $20 \cdot 4^{\mathrm{c}}$ \\
CP intake & $8^{\mathrm{a}}$ & $4 \cdot 4^{\mathrm{b}}$ & $0 \cdot 86^{\mathrm{d}}$ & $2 \cdot 0^{\mathrm{c}}$ & $2 \cdot 1^{\mathrm{c}}$ & $2 \cdot 5^{\mathrm{c}}$ & $2 \cdot 2^{\mathrm{c}}$ & $2 \cdot 3^{\mathrm{c}}$ \\
OM truly degraded (g/kg) & $704^{\mathrm{a}}$ & $612^{\mathrm{c}}$ & $582^{\mathrm{c}}$ & $655^{\mathrm{ab}}$ & $647^{\mathrm{b}}$ & $670^{\mathrm{a}}$ & $645^{\mathrm{b}}$ & $657^{\mathrm{ab}}$ \\
EMP (g microbial biomass/kg & $295^{\mathrm{c}}$ & $303^{\mathrm{c}}$ & $241^{\mathrm{d}}$ & $312^{\mathrm{bc}}$ & $333^{\mathrm{b}}$ & $344^{\mathrm{ab}}$ & $326^{\mathrm{b}}$ & $364^{\mathrm{a}}$ \\
OM truly degraded) & & & & & & & & \\
\hline
\end{tabular}

LH, lucerne (Medicago sativa L.) hay; OBH, Oat (Avenia sativa L.)-berseem clover (Trifolium alexandrinum cultivar BigBee) hay; MCR, maize (Zea mays L.) crop residue; OM, organic matter; $\mathrm{CP}$, crude protein; EMP, efficiency of microbial production.

a,b,c Mean values within a row with unlike superscript letters were significantly different $(P<0.05)$.

${ }^{*}$ For details of diets and procedures, see Table 1 and p. 626. 
Table 3. Gas volumes, substrate degradabilities and partitioning factors (PF) of soyabean meal, maize (Zea mays L.) grain, lucerne (Medicago sativa L.) hay, oat (Avenia sativa L.)-berseem clover (Trifolium alexandrinum cultivar BigBee) hay, maize crop residue and of diets (diets 1 to 5 ) measured at time of half asymptotic gas production $\left(t_{1 / 2}\right)$ and after $16.0 \mathrm{~h}$ of incubation* $\dagger$

\begin{tabular}{|c|c|c|c|c|c|c|c|c|c|c|}
\hline Variable & SBM & MG & LH & $\mathrm{OBH}$ & MCR & Diet 1 & Diet 2 & Diet 3 & Diet 4 & Diet 5 \\
\hline Gas asymptote $(\mathrm{V}, \mathrm{ml})$ & $149 \cdot 6^{\mathrm{ef}}$ & $234 \cdot 0^{\mathrm{g}}$ & $123 \cdot 6^{\mathrm{b}}$ & $112 \cdot 9^{a}$ & $138 \cdot 4^{\mathrm{C}}$ & $140 \cdot 9^{c}$ & $146 \cdot 3^{\mathrm{de}}$ & $144 \cdot 2^{d}$ & $144 \cdot 2^{d}$ & $151 \cdot 2^{f}$ \\
\hline Gas rate $(c, \%$ per $h)$ & $9 \cdot 01^{9}$ & $3 \cdot 23^{b}$ & $8 \cdot 16^{f}$ & $4.61^{\mathrm{d}}$ & $3.05^{\mathrm{a}}$ & $4 \cdot 22^{c}$ & $4 \cdot 19^{c}$ & $4.25^{\mathrm{c}}$ & $4.49^{d}$ & $4.85^{\mathrm{e}}$ \\
\hline Half-time $\left(t_{1 / 2}, h\right)$ & $7.69^{\mathrm{a}}$ & $21.5^{\mathrm{g}}$ & $8 \cdot 50^{\mathrm{b}}$ & $15 \cdot 1^{d}$ & $22 \cdot 7^{\mathrm{h}}$ & $16 \cdot 4^{\dagger}$ & $16 \cdot 5^{f}$ & $16 \cdot 3^{\dagger}$ & $15 \cdot 4^{\mathrm{e}}$ & $14 \cdot 3^{\mathrm{c}}$ \\
\hline Gas at $t_{1 / 2}(\mathrm{ml})$ & $71.9^{f}$ & $106 \cdot 8^{\mathrm{g}}$ & $55 \cdot 2^{\mathrm{a}}$ & $53.5^{\mathrm{a}}$ & $63 \cdot 3^{\mathrm{b}}$ & $66 \cdot 8^{\mathrm{C}}$ & $71 \cdot 1^{\text {ef }}$ & $67 \cdot 8^{\mathrm{cd}}$ & $70 \cdot 8^{\mathrm{e}}$ & $69.5^{\mathrm{de}}$ \\
\hline ivTDOM at $t_{1 / 2}(\mathrm{mg})$ & $374.5^{\mathrm{e}}$ & $425 \cdot 9^{f}$ & $251 \cdot 1^{d}$ & $202 \cdot 9^{\mathrm{b}}$ & $167 \cdot 6^{\mathrm{a}}$ & $216 \cdot 6^{\mathrm{c}}$ & $226 \cdot 8^{\mathrm{C}}$ & $228.0^{\mathrm{C}}$ & $230 \cdot 1^{c}$ & $263 \cdot 4^{\mathrm{d}}$ \\
\hline PF at $t_{1 / 2}(\mathrm{mg} / \mathrm{ml})$ & $5 \cdot 21^{f}$ & $3.99^{d}$ & $4.55^{\mathrm{e}}$ & $3.79^{c}$ & $2 \cdot 64^{\mathrm{a}}$ & $3 \cdot 10^{\mathrm{b}}$ & $3 \cdot 19^{b}$ & $3.36^{b}$ & $3 \cdot 25^{\mathrm{b}}$ & $3.70^{\mathrm{C}}$ \\
\hline Gas $16 \mathrm{~h}(\mathrm{ml})$ & $108 \cdot 6^{\mathrm{h}}$ & $90 \cdot 5^{9}$ & $85 \cdot 5^{\dagger}$ & $59 \cdot 5^{\mathrm{b}}$ & $53 \cdot 1^{a}$ & $72 \cdot 6^{\mathrm{c}}$ & $72 \cdot 1^{\mathrm{C}}$ & $70 \cdot 6^{\mathrm{c}}$ & $76.0^{d}$ & $80.0^{\mathrm{e}}$ \\
\hline ivTDOM $16 \mathrm{~h}(\mathrm{mg})$ & $414.7^{g}$ & $445 \cdot 3^{\mathrm{h}}$ & $292.5^{f}$ & $205 \cdot 3^{\mathrm{b}}$ & $158 \cdot 9^{a}$ & $217 \cdot 8^{\mathrm{C}}$ & $220 \cdot 3^{\mathrm{c}}$ & $235.1^{d}$ & $235.6^{\mathrm{d}}$ & $262 \cdot 4^{\mathrm{e}}$ \\
\hline $\mathrm{PF} 16 \mathrm{~h}(\mathrm{mg} / \mathrm{ml})$ & $3.81^{d}$ & $4.92^{\mathrm{e}}$ & $3.42^{b c}$ & $3.45^{\mathrm{c}}$ & $2.99^{\mathrm{a}}$ & $3.00^{\mathrm{a}}$ & $3.05^{a}$ & $3 \cdot 33^{b c}$ & $3.09^{\mathrm{a}}$ & $3 \cdot 28^{b}$ \\
\hline
\end{tabular}

SBM, soyabean meal; MG, maize grain; LH, lucerne hay; OBH, oat-berseem clover hay; MCR, maize crop residue; ivTDOM, in vitro truly degraded organic matter.

$\mathrm{a}, \mathrm{b}, \mathrm{c}, \mathrm{d}, \mathrm{e}, \mathrm{f}, \mathrm{g}, \mathrm{h}$ Mean values within a row with unlike superscript letters were significantly different $(P<0.05)$

* For details of diets and procedures, see Tables 1 and 2 and p. 626.

† Variables are related to the incubation of $500 \mathrm{mg}$ dry substrate.

degradabilities $\left(R^{2} 0.60, P=0 \cdot 02\right)$. Within diets, this relationship was again insignificant for gas volumes, but was significant for in vitro true OM degradabilities $\left(R^{2} 0 \cdot 78, P=0 \cdot 049\right)$. Within roughages, gas volumes and EMP in vivo were inversely related $\left(R^{2} 0 \cdot 99, P=0 \cdot 016\right)$, but this relationship was insignificant for in vitro true OM degradabilities. The PF and EMP in vivo of the five diets and MCR could be fitted onto the same regression line, which was better described by a curvilinear than a linear function (Fig. 1). The curvilinear function projected an asymptote of $386 \mathrm{~g}$ microbial biomass $/ \mathrm{kg}$ OM truly degraded in the rumen. Combined gas volumes of the diets and MCR were linearly related to EMP in vivo $\left(R^{2}\right.$ $0.65, P<0.05)$. This relationship was closer between in vitro true OM degradabilities and EMP in vivo $\left(R^{2} 0.94\right.$, $P<0 \cdot 001)$. No curvilinear regression of the kind reported in Fig. 1 could be fitted to these two latter relationships.

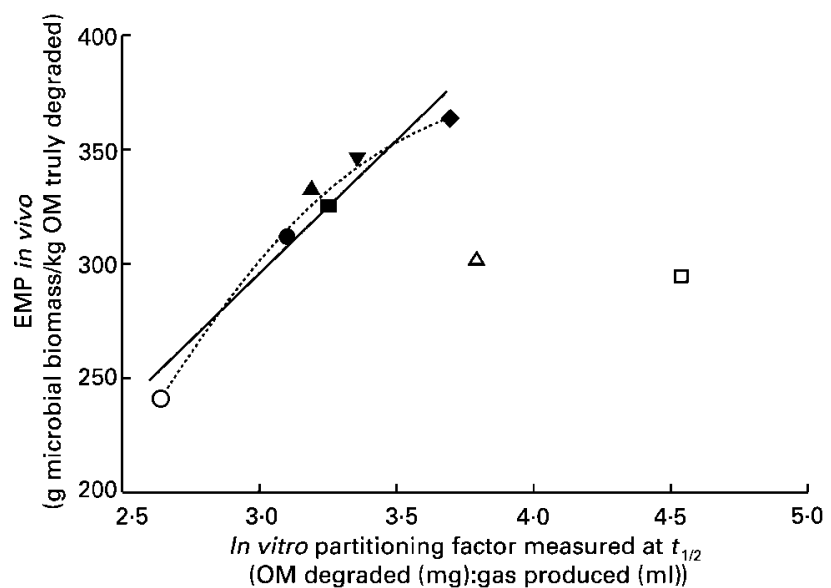

Fig. 1. Relationship between in vitro efficiency of microbial production (EMP) estimated by combined substrate degradability and gas volume measurements at time of half asymptotic gas production $\left(t_{1 / 2}\right)$ and EMP measured in sheep. OM, organic matter. $O$, Maize (Zea mays L.) crop residue; $\triangle$, oat (Avenia sativa L.)-berseem clover (Trifolium alexandrinum cultivar BigBee) hay; $\square$, lucerne (Medicago sativa L.) hay ( $P=0.33$ for roughages); $\bullet$, diet 1 ; $\boldsymbol{\Lambda}$, diet $2 ; \boldsymbol{\nabla}$, diet $3 ; \mathbf{\square}$, diet 4 ; $\diamond$, diet $5(P=0.04$ for diets 1 to 5$)$; ..., curvilinear $\left(R^{2} 0.99\right)$; - , linear $\left(R^{2} 0.93\right)$. For details of diets and procedures, see Tables 1 and 2 and p. 626 .
The relationship between the PF after $16.0 \mathrm{~h}$ of incubation and the EMP in vivo was significant for the roughages $(P=0.04)$, but insignificant for the diets (Fig. 2). The PF after $16.0 \mathrm{~h}$ and EMP in vivo of the five diets and MCR could not be fitted onto the same regression line. The relationship between the PF after $24.0 \mathrm{~h}$ and EMP in vivo tended to be significant for roughages $(P=0.07)$, but was insignificant for diets $(P=0 \cdot 66$; results not shown).

\section{In vitro fermentation products and their relationships}

SCFA production, $\mathrm{NH}_{3}$ concentration, total and proportional purine recovery and in vitro apparent DM degradabilities were measured after $16.0 \mathrm{~h}$ of incubation (Table 4). Acetate proportion was lowest in the concentrates and highest in the roughages. Isoacids and valerate were formed from SBM and were generally

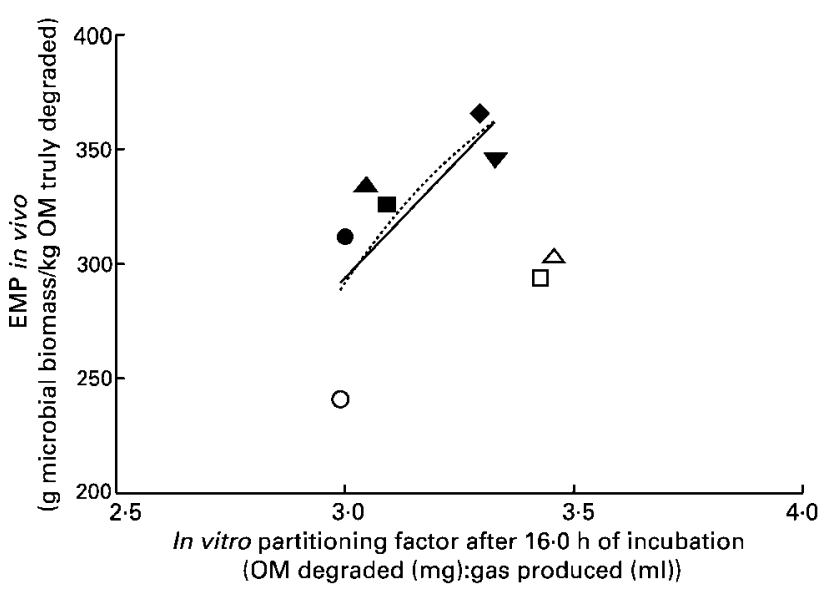

Fig. 2. Relationship between in vitro efficiency of microbial production (EMP) estimated by combined substrate degradability and gas volume measurements after $16.0 \mathrm{~h}$ of incubation and EMP measured in sheep. OM, organic matter. O, Maize (Zea mays L.) crop residue; $\triangle$, oat (Avenia sativa L.)-berseem clover (Trifolium alexandrinum cultivar BigBee) hay; $\square$, lucerne (Medicago sativa L.) hay (roughages $P=0.04) ; 0$, diet $1 ; \boldsymbol{\Lambda}$, diet $2 ; \boldsymbol{\nabla}$, diet $3 ; \boldsymbol{\square}$, diet 4 ; $\checkmark$, diet $5(P=0.08$ for diets 1 to 5$)$; ... curvilinear $\left(R^{2} 0.56\right)$; - linear $\left(R^{2} 0.51\right)$. For details of diets and procedures, see Table 1 and p. 626. 
Table 4. Short-chain fatty acid (SCFA) production, ammonia-nitrogen, total purine bases (PB), PB relative to ATP and in vitro apparent degradabilities of DM obtained from the incubation of diet components and of diets ${ }^{*} \dagger$

\begin{tabular}{|c|c|c|c|c|c|c|c|c|c|c|}
\hline Variable & SBM & MG & $\mathrm{LH}$ & $\mathrm{OBH}$ & MCR & Diet 1 & Diet 2 & Diet 3 & Diet 4 & Diet 5 \\
\hline SCFA (mmol) & $2 \cdot 70^{\mathrm{i}}$ & $1.47^{9}$ & $1.69^{h}$ & $1 \cdot 12^{b}$ & $1.02^{\mathrm{a}}$ & $1 \cdot 38^{\mathrm{ef}}$ & $1 \cdot 33^{\mathrm{cd}}$ & $1.31^{\mathrm{c}}$ & $1.42^{\mathrm{fg}}$ & $1.46^{9}$ \\
\hline $\begin{array}{l}\text { Acetate } \\
\text { (mmol/100 mmol total fatty acids) }\end{array}$ & $57 \cdot 5^{\mathrm{a}}$ & $58 \cdot 3^{\mathrm{b}}$ & $69 \cdot 7^{\mathrm{e}}$ & $71.4^{f}$ & $69 \cdot 3^{\mathrm{e}}$ & $66 \cdot 1^{\mathrm{c}}$ & $66 \cdot 3^{c}$ & $67 \cdot 2^{\mathrm{d}}$ & $66 \cdot 4^{c}$ & $67 \cdot 4^{d}$ \\
\hline $\begin{array}{l}\text { Propionate } \\
\text { (mmol/100 mmol total fatty acids) }\end{array}$ & $25 \cdot 2^{h}$ & $23 \cdot 5^{9}$ & $21 \cdot 1^{c}$ & $20 \cdot 1^{a}$ & $23 \cdot 8^{9}$ & $22 \cdot 9^{f}$ & $22 \cdot 3^{\mathrm{e}}$ & $20 \cdot 5^{\mathrm{b}}$ & $21 \cdot 8^{d}$ & $19 \cdot 8^{a}$ \\
\hline $\begin{array}{l}\text { Butyrate } \\
\text { (mmol/100 mmol total fatty acids) }\end{array}$ & $9 \cdot 2^{\mathrm{C}}$ & $15 \cdot 6^{\mathrm{h}}$ & $6 \cdot 0^{\mathrm{a}}$ & $6 \cdot 8^{b}$ & $6 \cdot 8^{\mathrm{b}}$ & $9 \cdot 0^{\mathrm{C}}$ & $9 \cdot 7^{d}$ & $10 \cdot 8^{f}$ & $9.9^{\mathrm{e}}$ & $11 \cdot 2^{\mathrm{g}}$ \\
\hline $\begin{array}{l}\text { Isobutyrate } \\
\text { (mmol/100 mmol total fatty acids) }\end{array}$ & $1.4^{\mathrm{e}}$ & $0.4^{\mathrm{c}}$ & $0.5^{\mathrm{d}}$ & $0.4^{c}$ & $0^{a}$ & $0.5^{\mathrm{d}}$ & $0.4^{c}$ & $0.3^{b}$ & $0.4^{\mathrm{c}}$ & $0.3^{b}$ \\
\hline $\begin{array}{l}\text { Valerate } \\
\text { (mmol/100 mmol total fatty acids) }\end{array}$ & $3.0^{9}$ & $1.0^{\mathrm{e}}$ & $2 \cdot 0^{f}$ & $1.0^{\mathrm{e}}$ & $0.5^{\mathrm{a}}$ & $0.8^{\mathrm{cd}}$ & $0.7^{\mathrm{c}}$ & $0.6^{\mathrm{b}}$ & $0.8^{\mathrm{cd}}$ & $1.0^{\mathrm{e}}$ \\
\hline $\begin{array}{l}\text { Isovalerate (mmol/ } 100 \mathrm{mmol} \\
\text { total fatty acids) }\end{array}$ & $3 \cdot 7^{f}$ & $1 \cdot 2^{\mathrm{e}}$ & $0.7^{c}$ & $0.3^{a}$ & $-\S$ & $0.7^{c}$ & $0.5^{\mathrm{b}}$ & $0.3^{a}$ & $0.5^{\mathrm{b}}$ & $0.3^{a}$ \\
\hline $\begin{array}{l}\mathrm{NH}_{3}(\mathrm{mg}) \\
\mathrm{PB}(\mu \mathrm{mol})\end{array}$ & $\begin{array}{r}15 \cdot 2^{\mathrm{a}} \\
8 \cdot 48^{\mathrm{e}}\end{array}$ & $\begin{array}{l}0.03^{g} \\
9.99^{f}\end{array}$ & $\begin{array}{l}3 \cdot 0^{b} \\
6 \cdot 81^{b}\end{array}$ & $\begin{array}{l}2 \cdot 2^{\mathrm{c}} \\
4 \cdot 94^{\mathrm{a}}\end{array}$ & $\begin{array}{l}0 \cdot 6^{f} \\
5 \cdot 02^{a}\end{array}$ & $\begin{array}{l}2 \cdot 5^{\mathrm{c}} \\
7 \cdot 14^{\mathrm{c}}\end{array}$ & $\begin{array}{l}1 \cdot 9^{d} \\
6 \cdot 73^{b}\end{array}$ & $\begin{array}{l}1 \cdot 2^{\mathrm{e}} \\
6 \cdot 81^{\mathrm{b}}\end{array}$ & $\begin{array}{l}1 \cdot 7^{\mathrm{d}} \\
7 \cdot 32^{\mathrm{c}}\end{array}$ & $\begin{array}{l}0 \cdot 8^{f} \\
7 \cdot 82^{d}\end{array}$ \\
\hline Adenine ( $\mu \mathrm{mol})$ & $4.57^{\mathrm{e}}$ & $4.73^{\mathrm{e}}$ & $3.03^{\mathrm{c}}$ & $2 \cdot 36^{\mathrm{a}}$ & $2 \cdot 48^{\mathrm{b}}$ & $3.49^{\text {cd }}$ & $3.24^{\mathrm{C}}$ & $3.29^{\mathrm{c}}$ & $3.51^{\mathrm{cd}}$ & $3.76^{\mathrm{d}}$ \\
\hline Guanine ( $\mu \mathrm{mol})$ & $3.91^{b}$ & $5 \cdot 26^{c}$ & $3.78^{b}$ & $2.58^{\mathrm{a}}$ & $2.54^{\mathrm{a}}$ & $3.65^{\mathrm{b}}$ & $3.49^{b}$ & $3.52^{b}$ & $3 \cdot 81^{\mathrm{b}}$ & $4 \cdot 06^{b}$ \\
\hline PB/ATP $(\mu \mathrm{mol} / \mathrm{mmol})$ & $1 \cdot 28^{\mathrm{a}}$ & $2.56^{\mathrm{g}}$ & $1.59^{\mathrm{b}}$ & $1.72^{\mathrm{C}}$ & $1.87^{d}$ & $2.00^{\text {ef }}$ & $1.94^{\mathrm{de}}$ & $1.98^{\mathrm{ef}}$ & $1.98^{\text {ef }}$ & $2.05^{f}$ \\
\hline $\operatorname{ivADDM}(\mathrm{mg})$ & $311.5^{f}$ & $178 \cdot 2^{d}$ & $197 \cdot 4^{\mathrm{e}}$ & $149 \cdot 4^{\mathrm{b}}$ & $125 \cdot 1^{\mathrm{a}}$ & $155 \cdot 1^{\mathrm{bc}}$ & $158 \cdot 1^{\mathrm{c}}$ & $150 \cdot 6^{b}$ & $159 \cdot 1^{\mathrm{C}}$ & $171 \cdot 4^{\mathrm{d}}$ \\
\hline
\end{tabular}

SBM, soyabean meal; MG, maize (Zea mays L.) grain; LH, lucerne (Medicago sativa L.) hay; OBH, oat (Avenia sativa L.)-berseem clover (Trifolium alexandrinum cultivar BigBee) hay; MCR, maize crop residue; ivADDM, in vitro apparently degraded DM.

a,b,c,d,e,f,g,h,i Mean values within a row with unlike superscript letters were significantly different $(P<0.05)$

${ }^{*}$ For details of diets and procedures, see Tables 1 and 2 and p. 626.

† Variables are related to the incubation of $500 \mathrm{mg}$ dry substrate.

$\S$ Negative value calculated.

$<2 \mathrm{mmol} / 100 \mathrm{mmol}$ total fatty acids in the other substrates. In the diet components, $\mathrm{NH}_{3}$ concentration was lowest in MG and highest in SBM. Significant differences in $\mathrm{NH}_{3}$ concentrations were also observed in the diets, and it can be calculated that their $\mathrm{NH}_{3}$ concentrations and EMP in vivo were strongly inversely related $\left(R^{2} 0.93, P=0.007\right)$. The highest purine concentration was found with $M G$ and lowest with OBH. Except for SBM, guanine concentration was higher than adenine concentration. It should be noted here that the purine contents in the non-incubated substrates were $5 \cdot 7,5 \cdot 7,6 \cdot 2,6 \cdot 3$ and $6 \cdot 1 \mu \mathrm{mol} / 500 \mathrm{mg}$ in SBM, MG, LH, OBH and MCR respectively. Purine yield per unit ATP produced $(\mu \mathrm{mol} / \mathrm{mmol})$ from the incubation of $500 \mathrm{mg}$ substrate ranged from 1.28 in soyabean meal to 2.56 in MG. There was no significant relationship between purine yield per unit ATP produced and EMP in vivo either across diets and roughages or within diets and roughages. The relationship tended to be inverse for the roughages $(P=0.22)$.

For diets and roughages, a strong relationship was found between stoichiometrically calculated and actually measured gas volumes (Fig. 3). In MG, measured gas volume was about $20 \%$ higher than the calculated value, while for SBM measured gas volume was less than the stoichiometrically calculated value by approximately $16 \%$. The relationship was described by the regression equation $y=24 \cdot 8+0.68 x\left(R^{2} 0 \cdot 89, P<0 \cdot 0001\right)$.

In vitro apparently degraded substrate was calculated by summation of the mass of $\mathrm{C}, \mathrm{H}$ and $\mathrm{O}$ recovered in SCFA and the mass of $\mathrm{C}, \mathrm{O}$ and $\mathrm{H}$ stoichiometrically calculated for $\mathrm{CO}_{2}, \mathrm{CH}_{4}$ and $\mathrm{H}_{2} \mathrm{O}$ produced. There was a very good agreement between in vitro apparent DM degradability as determined by high-speed centrifugation and in vitro apparent $\mathrm{DM}$ degradability calculated by $\mathrm{C}, \mathrm{O}$ and $\mathrm{H}$ balance
(Fig. 4). The relationship was described by the regression equation $y=-2 \cdot 0+1.0 x\left(R^{2} 0.98, P<0.0001\right)$.

In vitro truly degraded substrate was calculated as the sum of $\mathrm{C}, \mathrm{O}$ and $\mathrm{H}$ recovered in SCFA and fermentative $\mathrm{CO}_{2}, \mathrm{CH}_{4}$ and $\mathrm{H}_{2} \mathrm{O}$ plus the amount of microbial biomass produced (the latter calculated from purine production). The relationship between in vitro true OM degradability as measured by neutral-detergent solution treatment and calculated true degradability was strong, except for $\mathrm{MG}$, where the measured degradability was about $130 \mathrm{mg}$

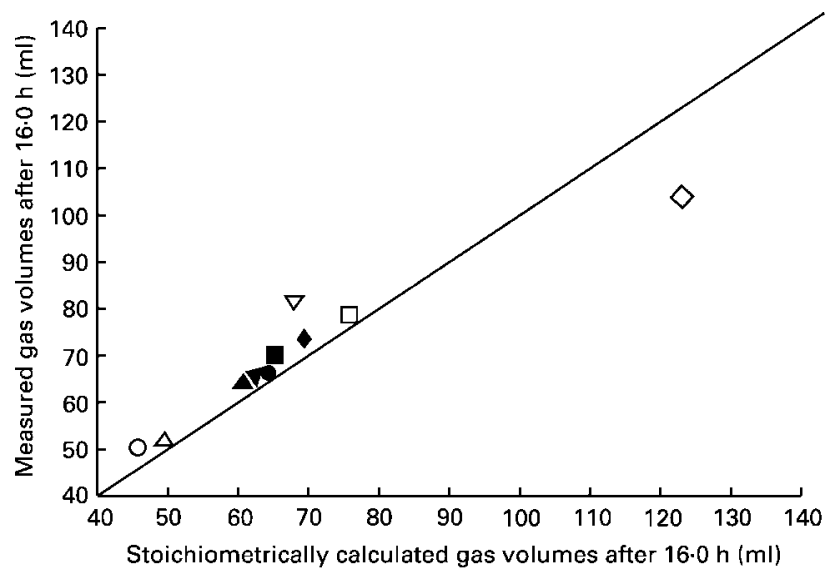

Fig. 3. Relationship between in vitro gas volumes stoichiometrically calculated from short-chain fatty acid recovery after $16.0 \mathrm{~h}$ of incubation and measured gas volumes. O, Maize (Zea mays L.) crop residue; $\triangle$, oat (Avenia sativa L.)-berseem clover (Trifolium alexandrinum cultivar BigBee) hay; $\square$, lucerne (Medicago sativa L.) hay; $\nabla$, maize grain; $\diamond$, soyabean meal; $\bullet$, diet 1 ; $\boldsymbol{\Delta}$, diet 2 ; $\mathbf{\nabla}$, diet 3 ; $\mathbf{\square}$, diet 4 ; $\bullet$, diet $5 ;-, y=x$. For details of diets and procedures, see Tables 1 and 2 and p. 626. 


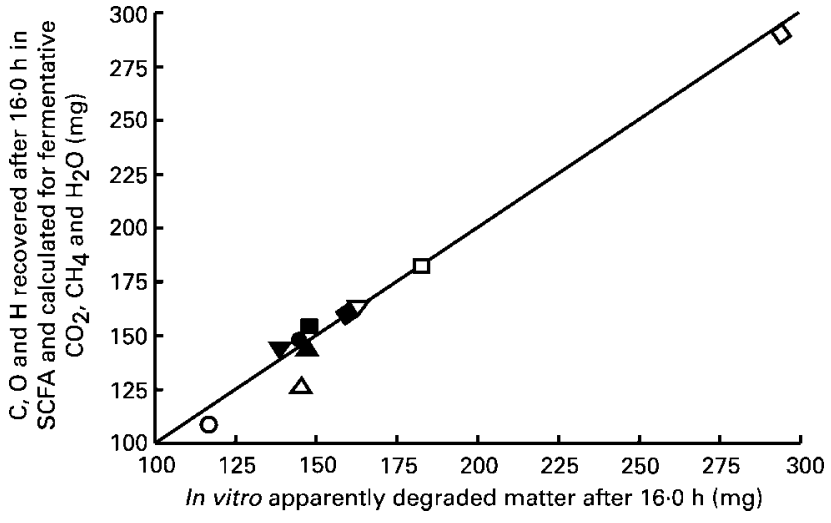

Fig. 4. Relationship between in vitro apparent degradability measured by high-speed centrifugation after $16.0 \mathrm{~h}$ of incubation and recovery of $\mathrm{C}, \mathrm{H}$ and $\mathrm{O}$ in short-chain fatty acids, (SCFA) and gases. O, Maize (Zea mays L.) crop residue; $\triangle$, oat (Avenia sativa L.)-berseem clover (Trifolium alexandrinum cultivar BigBee) hay; $\square$, lucerne (Medicago sativa L.) hay; $\nabla$, maize grain; $\diamond$, soyabean meal; $\bullet$, diet 1; $\mathbf{\Lambda}$, diet 2; $\mathbf{\nabla}$, diet 3; $\mathbf{\square}$, diet 4; $\bullet$, diet 5; -, $y=x$. For details of diets and procedures, see Tables 1 and 2 and p. 626.

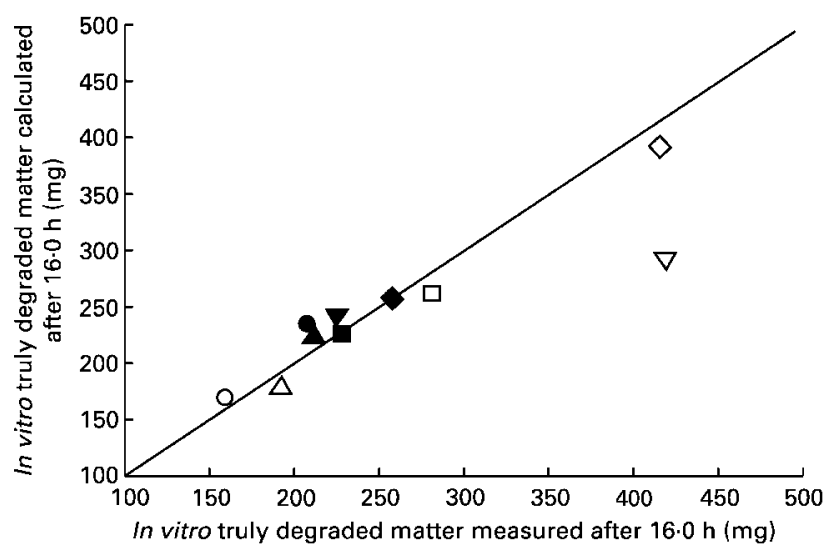

Fig. 5. Relationship between in vitro true organic matter degradability estimated by neutral detergent solution after $16.0 \mathrm{~h}$ of incubation and recovery of short-chain fatty acids, gases and microbial biomass. O, Maize (Zea mays L.) crop residue; $\Delta$, oat (Avenia sativa L.)-berseem clover (Trifolium alexandrinum cultivar BigBee) hay; $\square$, lucerne (Medicago sativa L.) hay; $\nabla$, maize grain; $\diamond$, soyabean meal; $\bullet$, diet $1 ; \boldsymbol{\Lambda}$, diet 2; $\boldsymbol{\nabla}$, diet 3 ; $\mathbf{\square}$, diet 4 ; $\bullet$, diet 5 . For details of diets and procedures, see Tables 1 and 2 and p. 626.

higher than the calculated value (Fig. 5). The relationship was described by the regression equation $y=84 \cdot 6+0 \cdot 62 x$ $\left(R^{2} 0 \cdot 81, P=0 \cdot 0004\right)$.

\section{Discussion}

Relationships between efficiency of microbial production in vitro and in vivo

As a high conversion of degraded feed into microbial biomass, i.e. high EMP, decreases the need for supplementing rumen undegradable feed protein and decreases the feed $\mathrm{C}$ flow into fermentative $\mathrm{CO}_{2}$ and $\mathrm{CH}_{4}$, high EMP is preferred over high SCFA production (Beever, 1993; Leng, 1993; Van Soest, 1994). The prediction of possible feed-related differences in EMP is, therefore, of considerable interest in feed analysis. In the present work, significant differences in EMP in vivo were found for both roughages and diets, even though the latter were designed by Karsli (1998) to provide uniformly the degradable intake of protein required for the synthesis of $130 \mathrm{~g}$ microbial protein $/ \mathrm{kg}$ total digestible nutrients consumed (National Research Council, 1996; level 1). These findings support the concept of varying EMP implicit in the Cornell net carbohydrate and protein system (National Research Council, 1996; level 2). Unfortunately, the analytical tools suggested by the Cornell net carbohydrate and protein system for the prediction of EMP are quite laborious and simpler techniques are required.

The results presented in Fig. 1 suggest that combined true degradability of substrate and gas volume measurements in vitro, i.e. PF analysis (Blümmel et al. 1997), is a promising technique with regards to the detection of variations in EMP. For diets, there was a significant relationship between PF values measured at $t_{1 / 2}$ and EMP in vivo, which accounted for $94 \%$ (non-linear relationship) of the variation in EMP. However, despite the relative time proximity between $\mathrm{PF}$ measurements at $t_{1 / 2}$ and after $16 \cdot 0 \mathrm{~h}$ of incubation (Table 3 ), this relationship was only close to significant $(P=0.08)$ when measured after $16.0 \mathrm{~h}$ and was insignificant $(P=0.66)$ when determined after $24.0 \mathrm{~h}$. The $24.0 \mathrm{~h}$ findings can be explained by a distortion of PF measurements through secondary fermentation of lysed microbial cells into SCFA and, consequently, of the gases after microbial peak yield (Blümmel \& Ørskov, 1993; Cone et al. 1997). Still, the $\mathrm{PF}$ value in diet 5 , for example, decreased by about $11 \%$, from $3.70\left(\mathrm{PF}\right.$ at $\left.t_{1 / 2}\right)$ to $3.28(\mathrm{PF}$ after $16.0 \mathrm{~h}) \mathrm{mg} /$ $\mathrm{ml}$ within the relative short incubation period from 14.3 to $16.0 \mathrm{~h}$ (Table 3 ). These findings suggest that for the kind of diets designed by Karsli (1998) detection of variations in EMP might require more laboratory input than PF analysis at only one fixed incubation time. The additional laboratory input consists of the incubation required for estimating asymptote and rate of gas production for the calculation of $t_{1 / 2}$.

For the roughages, time-uniform PF analysis after $16.0 \mathrm{~h}$ (and 24.0 h) of incubation was better related to EMP in vivo than PF analysis at $t_{1 / 2}$. This was caused by the high PF value of $\mathrm{LH}(4.55 \mathrm{mg} / \mathrm{ml})$ when determined at $t_{1 / 2}$, which was only $8.5 \mathrm{~h}$. It is possible that this $\mathrm{PF}$ value of $4.55 \mathrm{mg} / \mathrm{ml}$, which according to Blümmel et al. (1997) would indicate a $\mathrm{Y}_{\mathrm{ATP}}$ of approximately 32, presents an artifact caused by removal of still unfermented cellular components of LH soluble by neutral-detergent solution treatment, resulting in an overestimation of in vitro true OM degradability and consequently the PF value. This problem will be addressed in greater detail later on. Despite these reservations, theoretical PF values for diets calculated from $\mathrm{PF}$ values of dietary components at $t_{1 / 2}$ and the proportion of each component in a diet were strongly related to the in vivo EMP of diets $\left(R^{2} 0.93\right)$. These findings suggest that the in vivo EMP may be predicted from PF values of possible feed components.

Interestingly, the regression of the EMP in vivo on $\mathrm{PF}$ of diets and MCR at $t_{1 / 2}$ could be fitted onto one regression 
line, which was better $\left(R^{2} 0.99 v .0 .93\right)$ described by a non-linear than a linear function (Fig. 1). Both curvilinearity, as well as projected asymptote of EMP (386 g microbial biomass $/ \mathrm{kg}$ OM truly degraded in the rumen), agree well with the findings on maximum EMP (in the presence of protozoa) reported by Russell et al. (1992) and Van Soest (1994). For LH and OBH, estimates of EMP in vitro by PF analysis were consistently higher than the respective EMP in vivo (Figs 1 and 2). Crude protein content was higher in these two roughages than in diets and MCR, and this crude protein might have been used more efficiently for microbial synthesis in vitro, where no absorption and passage of $\mathrm{NH}_{3}$ occurs, than in vivo. It can be calculated from in situ results on $\mathrm{N}$ and $\mathrm{OM}$ degradation of the $\mathrm{LH}$ and OBH (Karsli, 1998) that rumen $\mathrm{N}$ availability in $\mathrm{LH}$ was much higher than the OM availability, which might have resulted in a less than optimal EMP in vivo (Sinclair et al. 1995; Witt et al. 1999). Similarly, Blümmel et al. (2001) calculated the synchronization indices of $\mathrm{N}: \mathrm{OM}$ fermentation of the five diets according to Sinclair et al. (1995) and Witt et al. (1999) and concluded that both overall $\mathrm{N}$ and synchronization of $\mathrm{N}: \mathrm{OM}$ fermentation was insufficient for maximum EMP. However, in the current in vitro work, $\mathrm{NH}_{3}$ was still present in the diet incubation (Table 4), which does not support the assumption of $\mathrm{N}$ as the primarily limiting factor for EMP. Interestingly, the $\mathrm{NH}_{3}$ concentration of the diets in vitro was highly negatively related to the EMP in vivo $\left(R^{2} 0.93\right)$ and differences in the EMP are therefore probably less due to lack of total $\mathrm{N}$ and more to microbial inefficiencies in utilizing it.

In the roughage incubations, the PF analysis after 16.0 and $24.0 \mathrm{~h}$ ranked the roughages in the same order as the EMP in in vivo determinations, the relationship being significant for the PF after $16.0 \mathrm{~h}$ (Fig. 2), but not for the PF after $24.0 \mathrm{~h}(P=0.07)$. The $24.0 \mathrm{~h}$ incubation time was apparently too long for $\mathrm{LH}$, considering the short $t_{1 / 2}$ $(8.5 \mathrm{~h})$ of this roughage, resulting in a low PF value after $24.0 \mathrm{~h}$ because of microbial lysis. However, only three roughages have been investigated in the present work and caution is, therefore, required to not over-interpret these results.

\section{Relationships between in vitro fermentation products}

The concept of PF analysis demands a close stoichiometrical relationship between SCFA and gas production and a reliable determination of true degradability of the substrate. In the present work, gas volumes of diets and roughages were well predicted by SCFA analysis and the application of the stoichiometrical relationships outlined by Wolin (1960). In MG, however, more gas was measured than was stoichiometrically calculated, while the reverse was true for SBM (Fig. 3). The latter findings agree with results reported by Blümmel et al. (1999a) obtained with SBM of a different provenance. These authors concluded that the stoichiometrical relationship between SCFA and gas production is not good for feeds with a crude protein content $>400 \mathrm{~g} / \mathrm{kg}$.

A possible explanation for this observation resides with the high production of $\mathrm{NH}_{3}$ in these feeds, ultimately impairing the bicarbonate buffering system in the in vitro gas test (Cone 1998; Blümmel et al. 1999a). Thus, even though SCFA are produced, the buffering effect does not necessarily allow the expulsion of $\mathrm{CO}_{2}$ into the gas phase. In the bicarbonate-buffered gas test with an intact buffering mechanism, approximately $50 \%$ of the total gas volume consists of $\mathrm{CO}_{2}$ originating from buffering the SCFA produced (Blümmel \& Ørskov, 1993). More gas was measured in the MG incubation than was accounted for by SCFA analysis and stoichiometrical calculations. Lactate was not analysed in the present work because several authors (Steingass \& Menke, 1986; Getachew et al. 1998) have shown the buffering capacity of the employed in vitro test to be adequate for maintaining $\mathrm{pH}>6$ in concentrate and starch incubations. These $\mathrm{pH}$ conditions do not favour lactate production.

Nevertheless, buffering of lactate would lead to gas production, but, besides the unfavourable $\mathrm{pH}$ conditions mentioned earlier, it appears unlikely that lactate was produced to any significant extent for another reason. There was a very good agreement between the amount of substrate apparently degraded in vitro, as determined by highspeed centrifugation and the amount of $\mathrm{C}, \mathrm{O}$ and $\mathrm{H}$ recovered in SCFA, and calculated for fermentative $\mathrm{CO}_{2}, \mathrm{CH}_{4}$ and $\mathrm{H}_{2} \mathrm{O}$ (Fig. 4). Were lactate in the $\mathrm{MG}$ incubation responsible for the stoichiometrical underestimation of gas production, more substrate should have been apparently degraded than recovered in SCFA and fermentative $\mathrm{CO}_{2}, \mathrm{CH}_{4}$ and $\mathrm{H}_{2} \mathrm{O}$, but this was not the case. More work is required to understand why more gas was recovered in MG than was accounted for by SCFA, and it appears worthwhile investigating if the complete uptake of $\mathrm{NH}_{3}$ (very little $\mathrm{NH}_{3}$ was recovered after terminating the MG; Table 4) was responsible, possibly due to some mechanism converse to the one observed in SBM (excess $\mathrm{NH}_{3}$ ). However, lactate analysis should be included in this work.

\section{Gravimetrically determined true degradability and recovery of fermentation products}

As mentioned earlier, reliable determination of true substrate degradability is a second condition for meaningful $\mathrm{PF}$ analysis. The relationship between in vitro true OM degradability, as determined by neutral-detergent solution treatment, and true $\mathrm{OM}$ degradability calculated as the sum of $\mathrm{C}, \mathrm{H}$ and $\mathrm{O}$ recovered as SCFA, $\mathrm{CO}_{2}, \mathrm{CH}_{4}$ and $\mathrm{H}_{2} \mathrm{O}$ plus the microbial biomass produced, is presented in Fig. 5. There was a good agreement between measured and calculated true degradability for the diets and most of the diet components, confirming that neutral-detergent solution treatment achieves an effective separation of microbes and undegraded feed, thereby yielding a reliable estimate of true feed degradability (Van Soest, 1994). However, neutral-detergent solution-derived in vitro degradability in MG was about $130 \mathrm{mg}$ higher than was accounted for by the fermentation products (Fig. 5). The low rate of gas production from MG $(3.23 \%$ perh, Table 3 ) strongly suggests that not all the starch was fermented after $16.0 \mathrm{~h}$ of incubation. Starch can be soluble in neutral-detergent solution (Van Soest, 1994) and 
removal of unfermented starch is probably responsible for the high discrepancy between the measured and calculated true degradability evident in MG. It appears that determinations of in vitro true degradability of pure, high-starch concentrates by neutral-detergent solution treatment are potentially prone to substantial analytical errors, resulting in an overestimation of degradability.

In the balance of fermentation products, microbial biomass was estimated by purine analysis. It should be mentioned here that the relationship between $16.0 \mathrm{~h}$ purine production per unit ATP and EMP in vivo was insignificant for diets and roughages, the relationship tending to be inverse for the roughages. The purine contents of nonincubated diet components was on average $6.00 \mu \mathrm{mol} /$ $500 \mathrm{mg}$, which appears high when compared with the purine yield after incubating the five substrates for $16.0 \mathrm{~h}$ (mean value $7.05 \mu \mathrm{mol} / 500 \mathrm{mg}$; see Table 4). Even though McAllan \& Smith $(1973 a, b)$ suggested that feed purines are completely degradable in the rumen, Djouvinov et al. (1998) have recently shown the effective feed purine degradability in the rumen to be dependent on incubation time. This could affect in vitro measurements where the entire apparently undegraded pellet was analysed for purines after a short $(16.0 \mathrm{~h})$ incubation period relative to rumen retention times. Studies of the kind presented in Fig. 5 should therefore be confirmed using different microbial markers.

\section{Complementarity of measurements of substrate disappearance and of fermentation products}

Gravimetric methods measuring substrate disappearance have frequently been criticized on the grounds that substrate may be lost, for example by solubilization or filtration, without having actually being fermented (Menke et al. 1979; Blümmel \& Ørskov, 1993; Groot et al. 1998; Pell et al. 1998) and these concerns can be justified (see Fig. 5). These reservations provided a strong rationale for the development of feed evaluation systems based on in vitro gas production (Menke et al. 1979). Blümmel et al. (1997), on the other hand, have argued that measurement of only one fermentation product, particularly of gases that are waste products, is questionable unless the proportionality of fermentation products, including SCFA, gases and microbial biomass, is constant. If this relationship is not constant, gravimetric measurement of true substrate degradability (Goering \& Van Soest, 1970) provides a more convincing concept.

Yet more information about the fermentation can be obtained by combining true degradability and gas volume measurements. The results presented in the present study support this hypothesis, despite the occasional problems encountered with neutral-detergent solution treatment in the in vitro determination of true OM degradability discussed earlier. For example, in vitro true OM degradability of diets measured at $t_{1 / 2}$ was significantly related to their EMP in vivo, while gas volume at $t_{1 / 2}$ was not. In vitro OM degradability measured at $t_{1 / 2}$ is probably a good indicator of the rate of substrate degradation. As high substrate degradability rates decrease microbial maintenance requirements, EMP is potentially increased (Pirt, 1982;
Russell et al. 1992). The problem associated with measuring in vitro gas production only is also manifest in the roughage incubation, where gas volumes at $t_{1 / 2}$ and EMP in vivo were inversely related $(P=0 \cdot 02)$. MCR had a higher $(P<0 \cdot 05)$ gas volume at $t_{1 / 2}$ than $\mathrm{LH}$ and $\mathrm{OBH}$, reflecting a proportionally higher conversion of degraded substrate into SCFA and gases. In a related context, after $16.0 \mathrm{~h}$ of incubation the mean purine production from $500 \mathrm{mg}$ of the mixed diets was $7.16 \mu \mathrm{mol}$. It can be calculated from the purine content of components and their proportion in the diet that only $6.06 \mu \mathrm{mol}$ purines were to be expected, assuming additive effects, i.e. the associative effect of supplementation on purine yield was about $18 \%$. On the other hand, mean SCFA yield from the incubation of $500 \mathrm{mg}$ mixed diets was $1.38 \mathrm{mmol}$, while 1.29 mmol SCFA were to be expected from additive effects of SCFA production from the incubation of the dietary components. i.e. the associative effect on SCFA was only about $7 \%$ (calculated from Table 4).

In conclusion, nutritionally significant variations were found in the proportions of rumen fermentation products, including microbial biomass yield. In vitro degradability measurements were related to EMP in vivo in a more meaningful manner than gas volume measurements, but more comprehensive information about substrate degradation was obtained by combining both measurements. Therefore, to achieve a high EMP it appears sensible to suggest the selection of feeds with a high true degradability and low gas production in proportion to the amount of substrate degraded.

\section{Acknowledgement}

The authors would like to thank Dr H. Steingass from the Institute for Animal Nutrition (450), University of Hohenheim, 70593 Stuttgart, Germany, for assistance with the in vitro and $\mathrm{GC}$ analysis.

\section{References}

Adamu AM, Russell JR, McGillard AD \& Trenkle A (1989) Effects of added dietary urea on the utilization of maize stover silage by growing beef cattle. Anim Feed Sci Technol 22, 227-236.

Agriculture and Food Research Committee (1993) Energy and Protein Requirement of Ruminants. An Advisory Manual Prepared by the AFRC Technical Committee on Response to Nutrients. Wallingford, Oxon: CAB International.

Aiple KH (1993) Vergleichende Untersuchungen mit Pansensaft und Kot als Inoculum im Hohenheimer Futterwerttest (Comparisons of rumen and faecal inoculum in the Hohenheim Feed Evaluation Test). PhD Thesis, Universität Hohenheim.

Ausschuss für Bedarfsnormen der Gesellschaft für Ernährungsphysiologie der Haustiere (1986) Energie- und Nährstoffbedarf landwirschaftlicher Nutztiere. $\mathrm{Nr}$ 3. Milchkühe und Aufzuchtrinder (Energy and nutrient requirement of farm animals). Frankfurt (Main): DLG-Verlag.

Beever DE (1993) Ruminant animal production from forages present position and future opportunities. In Grassland for Our World [M Baker, editor]. Wellington: SIR Publishing.

Beuvink JMW \& Spoelstra SF (1992) Interaction between substrate, fermentation end-products, buffering systems and 
gas production upon fermentation of different carbohydrates by mixed rumen microorganism in vitro. Appl Microbiol Biotechnol 37, 505-509.

Blümmel M, Aiple K-H, Steingass H \& Becker K (1999a) A note on the stoichiometrical relationship of short chain fatty acid production and gas formation in feedstuffs of widely differing quality. J Anim Physiol Anim Nutr 81, 157-167.

Blümmel M \& Becker K (1997) The degradability characteristics of fifty-four roughages and roughage neutral-detergent fibre as described by in vitro gas production and their relationship to voluntary feed intake. Br J Nutr 77, 757-786.

Blümmel M, Krishna N \& Ørskov ER (2001) Supplementation strategies for optimizing ruminal carbon and nitrogen utilization: concepts and approaches. In Review Papers: 10th Animal Nutrition Conference, Karnal, India, November 9th to 11th 2001, pp. 10-23. Karnal, Haryana, India: Animal Nutrition Society of India.

Blümmel M, Makkar HPS \& Becker K (1997) In vitro gas production - a technique revisited. J Anim Physiol Anim Nutr 77, 24-34.

Blümmel M, Moss A, Givens I, Makkar HPS \& Becker K (1999b) Preliminary study on the relationship of microbial efficiencies of roughages in vitro and methane production in vivo. Proc Soc Nutr Physiol 8, 76 Abstr.

Blümmel M \& Ørskov ER (1993) Comparison of in vitro gas production and nylon bag degradability of roughages in predicting feed intake in cattle. Anim Feed Sci Technol 40, 109-119.

Brown WF \& Pittman WD (1991) Conservation and degradation of nitrogen and fiber fraction in selected tropical grasses and legumes. Trop Grassl 25, 305.

Clark JH, Klusmeyer TH \& Cameron MR (1992) Microbial protein synthesis and flow of nitrogen fractions to the duodenum of dairy cows. J Dairy Sci 75, 2304.

Cone JW (1998) Influence of protein fermentation on gas production profiles. Proc Soc Nutr Physiol 7, 36 Abstr.

Cone JW, Van Geldern AH \& Driehuis F (1997) Description of gas production profiles with a three-phasic model. Anim Feed Sci Technol 66, 31-45.

Djouvinov DS, Nakashima Y, Todorov N \& Pavlov D (1998) In situ degradation of feed purines. Anim Feed Sci Technol 71, 67-77.

Fox DG, Sniffen CJ, O'Connor JD, Van Soest PJ \& Russell JB (1992) A net carbohydrate and protein system for evaluating cattle diets. III Cattle requirement and diet adequacy. I Anim Sci 70, 3578-3596.

Getachew G, Blümmel M, Makkar HPS \& Becker K (1998) In vitro gas measuring techniques for assessment of nutritional quality of feeds: a review. Anim Feed Sci Technol 72, $261-281$.

Goering HK \& Van Soest PJ (1970) Forage Fiber Analyses (Apparatus, Reagents, Procedures and Some Applications). Agricutural Handbook no. 379. Washington, DC: USDA-ARS.

Groot JC, Williams BA, Oostam AJ, Boer H \& Tamminga S (1998) The use of cumulative gas and volatile fatty acid production to predict in vitro fermentation kinetics of Italian ryegrass leaf cell walls and contents at various time intervals. Br J Nutr 79, 519-525.

Karsli MA (1998) Ruminal microbial protein synthesis in sheep fed forages of varying nutritive value. $\mathrm{PhD}$ Thesis, Iowa State University.

Leng RA (1993) Quantitative ruminant nutrition - a green science. Aust J Agric Sci 44, 363-380.
McAllan AB \& Smith RH (1973a) Degradation of nucleic acid derivatives in the rumen. Br J Nutr 29, 331-342.

McAllan AB \& Smith RH (1973b) Degradation of nucleic acid derivatives by rumen bacteria in vitro. Br J Nutr 29, 467-474.

Makkar HPS \& Becker K (1999) Purine quantification in digesta from ruminant animals by spectophotometric and HPLC methods. Br J Nutr 81, 107-111.

Menke KH, Raab L, Salewski A, Steingass H, Fritz D \& Schneider W (1979) The estimation of the digestibility and metabolizable energy content of ruminant feedstuffs from the gas production when they are incubated with rumen liquor. J Agric Sci 93, 217-222.

National Research Council (1996) Nutrient Requirement of Beef Cattle. Washington, DC: National Academy Press.

Pell AN, Pitt RE, Doane PH \& Schofield P (1998) The development, use and application of the gas production technique at Cornell University, USA. In In vitro Techniques for Measuring Nutrient Supply to Ruminants, pp. 45-54 [ER Deaville, E Owens, AT Adegosan, C Rymer, JA Huntington and TLJ Lawrence, editors]. Edinburgh: BSAS.

Pirt SJ (1982) Maintenance energy: a general model for energylimited and energy-sufficient growth. Arch Microbiol 133, 300-302.

Rojas-Bourillon A, Russell JR, Trenle A \& McGillard AD (1987) Effects of rolling on the composition and utilization by growing steers of whole-plant corn silages. J Anim Sci 64, 303-311.

Russell JB, O'Connor JD, Fox DG, Van Soest PJ \& Sniffen CJ (1992) A net carbohydrate and protein system for evaluating cattle diets. I Ruminal fermentation. J Anim Sci 70, 3551-3561.

Sinclair LA, Garnsworthy PC, Newbold JR \& Buttery PJ (1995) Effects of synchronizing the rate of dietary energy and nitrogen in diets with similar carbohydrate composition on rumen fermentation and microbial protein synthesis in sheep. J Agric Sci 124, 463-472.

Sniffen CJ, O'Connor JD, Van Soest PJ, Fox DG \& Russell JB (1992) A net carbohydrate and protein system for evaluating cattle diets. II Carbohydrate and protein availability. J Anim Sci 70, 3562-3577.

Steingass H \& Menke KH (1986) Schätzung des energetischen Futterwertes aus der in vitro mit Pansensaft bestimmten Gasbildung und der chemischen Analyse (Estimation of the energy content of feedstuffs from in vitro gas production and chemical analysis). Übersicht Tierernähr 14, 251-270.

Tilley JMA \& Terry RA (1963) A two stage technique for the in vitro digestion of forage crops. J Br Grassl Soc 18, 104-111.

Van Soest PJ (1994) Nutritional Ecology of the Ruminant, 2nd ed., Ithaca, NY: Cornell University Press.

Van Soest PJ \& Robertson JB (1985) A Laboratory Manual for Animal Science no. 612. Ithaca, NY: Cornell University Press.

Witt MW, Sinclair LA, Wilkinson RG \& Buttery PJ (1999) The effect of synchronizing the rate of dietary energy and nitrogen supply to the rumen on the production and metabolism of sheep: food characterization and growth and metabolism of ewe lambs given food ad libitum. Anim Sci 69, 223-236.

Wolin MJ (1960) A theoretical rumen fermentation balance. $J$ Dairy Sci 43, 1452-1459.

Zinn RA \& Owens FN (1986) A rapid procedure for purine measurement and its use for estimating net ruminal protein synthesis. Can J Anim Sci 66, 157-166. 